\title{
Research of Curing Time and Temperature-Dependent Strengths and Fire Resistance of Geopolymer Foam Coated on an Aluminum Plate
}

\author{
Van Su Le *(D) and Petr Louda (D) \\ Department of Material Science, Faculty of Mechanical Engineering, Technical University of Liberec, \\ Studentská 2, 46117 Liberec, Czech Republic; petr.louda@tul.cz \\ * Correspondence: su.le.van@tul.cz or longsuvp90@gmail.com
}

Citation: Le, V.S.; Louda, P. Research of Curing Time and

Temperature-Dependent Strengths and Fire Resistance of Geopolymer Foam Coated on an Aluminum Plate. Coatings 2021, 11, 87. https://

doi.org/10.3390/coatings11010087

Received: 20 November 2020

Accepted: 12 January 2021

Published: 14 January 2021

Publisher's Note: MDPI stays neutral with regard to jurisdictional clai$\mathrm{ms}$ in published maps and institutional affiliations.

Copyright: (C) 2021 by the authors. Licensee MDPI, Basel, Switzerland. This article is an open access article distributed under the terms and conditions of the Creative Commons Attribution (CC BY) license (https:// creativecommons.org/licenses/by/ $4.0 /)$.

\begin{abstract}
Geopolymer foam (GF) uses a potassium activator and can be cured at high temperatures, which can improve its mechanical properties. In this study, we attempted to test this hypothesis by comparing the flexural and compressive strength, apparent density and fire resistance of GF. The composition of the GF used in the experiment included a potassium activator, basalt ground fiber and aluminum powder with a mass ratio to the binder of $0.45,0.3$ and 0.015 , respectively. The samples were cured at room temperature and at $50,70,85$ and $105^{\circ} \mathrm{C}$ with a curing time of $2,4,6,12$ and $24 \mathrm{~h}$. Then, the samples were kept until being tested on the third, seventh, 14th and 28th day. The results showed that the flexural and compressive strength and apparent density improved and stabilized after seven days at $85^{\circ} \mathrm{C}$. Furthermore, the GF exhibited a substantial increase after three days in its flexural strength by $111 \%$ and compressive strength by $122.9 \%$ at the optimal temperature of $85{ }^{\circ} \mathrm{C}$ for $2 \mathrm{~h}$ compared to the values at RT after 28 days. The GF had an apparent density of $0.558-0.623 \mathrm{~g} / \mathrm{cm}^{3}$ on the 28th day. As a new alternative to aluminum materials, investigating the fire resistance of sandwich panels (an aluminum plate covered with a GF layer) is important for their safe impregnation. Sandwich panels with thicknesses of 10-20 mm were exposed to a gas fire. The test results showed that the sandwich panels had significantly improved fire resistance compared to unprotected panels. The longest fire resistance times for the aluminum plate coated with $20 \mathrm{~mm}$ of GF layer thickness was $7500 \mathrm{~s}$. Thus, the GF coated on the aluminum plate exhibited superior fire resistance and a reduced heat transfer rate compared to uncoated panels.
\end{abstract}

Keywords: strength; aluminum; potassium activator; coating; recycling; foam; fire resistance

\section{Introduction}

Research into geopolymerized materials is a research trend of sustainable models; these are studied to create environmentally friendly production processes, reduce $\mathrm{CO}_{2}$ emissions and utilize industrial wastes such as fly ash, red mud, furnace slag, etc., to create products with high usability. The wide geopolymer applications make chemical anticorrosive products useful for fast-curing applications in the high-tech field and in medicine; this is especially true for geopolymer foam (GF) as a fire-resistant material. This study is part of a series of studies from the Technical University of Liberec (TUL) on geopolymer composites. The sources of raw materials such as basalt fiber, furnace slag and sand to produce GF have become rich and varied. However, the selection of the materials involved in forming geopolymers is still based on the priority criteria of minimizing industrial waste and increasing environmental sustainability. The curing process of the geopolymer composite has a significant impact on the quality and durability of the material, particularly as a result of curing temperature and time. The recommended curing temperature of geopolymer composite is in the temperature range of room temperature (RT) to $135^{\circ} \mathrm{C}$ [1-9]. Pavel Rovnaník [10] reported that the compressive strength of metakaolin-based geopolymer was reduced and its pore size increased as the sample curing temperature was increased to 
$80^{\circ} \mathrm{C}$. Bai et al. [9] showed a reduction in the compressive strength of metakaolin-based geopolymer foams with high total porosity. Hamad [11] indicated that the small size of specimens gave a higher compressive strength to high-performance lightweight foamed concrete compared to other sizes. GF has been widely considered for application in the field of fire-resistant materials due to its special properties such as low thermal conductivity, high temperature resistance and very light weight. Therefore, research into the application of GF for fire-retardant purposes is important. Studies on GF have used it as a surface coating to protect substrate materials such as wood, concrete and metal [12-14] Davidovits et al. [12] reported on a panel manufacturing process in which a panel coated with a layer of an alkaline silicate mixture was cured a temperature of at least $80^{\circ} \mathrm{C}$. Sakkas et al. [13] showed that a concrete slab coated with a $50 \mathrm{~mm}$ thick K-geopolymer layer significantly improved the fire-resistance of the material as a thermal barrier. Temuujin et al. [14] indicated that the adhesion of the metakaolin-based geopolymer coatings strongly depended on the composition of the material coated on metal substrates as thermal barriers.

GF is a lightweight material with a density of 200 to $1000 \mathrm{~kg} / \mathrm{m}^{3}[1,2,15]$, stability at high temperatures $[16,17]$ and fire-retardance in the case of the geopolymer having a potassium activator $[13,18,19]$, being quickly installed at low-temperatures [20-23] and having thermal insulation [24-28]. GFs are considered as building materials [29-35], membranes and membrane supports [36-38], adsorbents and fillers [39-42] and catalysts [17,43]. The processing method of GFs is the thermal expansion of K-nano-poly(siloxo) at temperatures above $250^{\circ} \mathrm{C}$. In addition, GFs can be produced by the geochemical method using foaming agents such as hydrogen peroxide $\left(\mathrm{H}_{2} \mathrm{O}_{2}\right)[44,45]$, aluminum powder $[23,26,35]$, sodium perborate [31] and silica fume [46,47]. GFs can develop into a low-density material with thermal insulation properties using thermal expansion agents or chemical methods [48].

Stone wool fiber is a base-building material with insulation properties that is used for buildings and furnace applications. It has good properties such as being light-weight, insulated and suitable for application to temperatures below $700{ }^{\circ} \mathrm{C}$; furthermore, it has a high melting point $1500{ }^{\circ} \mathrm{C}$ and is an environmentally friendly material. In addition to its application in insulation, it improves the mechanical strength of concrete. Light-weight fiber-reinforced geopolymer can be used up to the high temperature of $1000^{\circ} \mathrm{C}$ [49]. Fiberreinforced GF has been shown to have good mechanical and heat-resistant properties [10]. The output of this fiber by the Rockwool Company is about 300 kilotons per year; as the manufacturer declares, the recycling rate of this yarn is $100 \%$. To increase the recycled applications for this fiber, we made GF-reinforced milled fiber to create a cheap geopolymer product with good enough properties for high-temperature resistance.

There is very little research on the optimum curing conditions for geopolymers. In particular, the studies into the optimal curing conditions of GF are based on the evaluation of its durability criteria. Studies on the optimal curing conditions of GF are very important as they help to reduce the time and cost of the production process. Besides, to the authors' knowledge, there has been no research into fibers used for fire-resistant purposes in aluminum sheets covered with protective geopolymer layer-reinforced ground fiber.

This work presents the mechanical properties of GF that were developed in different curing temperatures and time conditions. The optimum condition for the curing of GF was synthesized and investigated in terms of its compressive and flexural strength and apparent density. The composition of the GF used in the experiment included potassium activator, basalt ground fiber and aluminum powder with a mass ratio to the binder of 0.45 , 0.3 and 0.015 , respectively. The samples were cured at room temperature and 50, 70, 85 and $105{ }^{\circ} \mathrm{C}$ with a curing time of $2,4,6,12$ and $24 \mathrm{~h}$. Then, the samples were kept until they were tested on the third, seventh, 14th and 28th day. The fire resistance tests analyzed the fire resistance of the aluminum plate coated by the GF layer. The composition of the studied GF was taken from previous research, with GF types prepared at room temperature as the mixture, has excellent mechanical properties at the age of 28 days. 


\section{Materials and Methods}

\subsection{Materials}

Baucis LK-type cement is commercially distributed by the company České Lupkové Závody a.s, Nove Straseci, Czech Republic, and was used as the inorganic material. Aluminum powder (pkchemie Inc., Trebic, Czech Republic) was used to create porosity in the GF structure. It had a chemical composition of $99.4 \% \mathrm{Al}, 0.16 \% \mathrm{Fe}, 0.06 \% \mathrm{Si}$ and $0.001 \% \mathrm{Cu}$ by weight, and the average grain size D50 was $51.47 \mu \mathrm{m}$. Ground fiber was used in the experimental work as a reinforcement material. To obtain ground fibers, a stone wool slab (manufactured by Saint-Gobain Construction Product, CZ a.s., Sokolovska, Czech Republic) was milled. It had a density of $150 \mathrm{~kg} / \mathrm{m}^{3}$, thermal conductivity $0.037 \mathrm{~W} /(\mathrm{mK})$ and range of temperature operation of up to $700{ }^{\circ} \mathrm{C}$. Chemical element compositions of raw materials are described in Table 1 and were measured by a scanning electron microscope-ZEISS Ultra Plus-fitted with an energy-dispersive spectroscope (EDS) and operated at $15 \mathrm{kV}$ (ZEISS, Berlin, Germany).

Table 1. Chemical element compositions of raw materials.

\begin{tabular}{cccccccccccccc}
\hline Constituents & $\mathbf{O}$ & $\mathbf{S i}$ & $\mathbf{C a}$ & $\mathbf{A l}$ & $\mathbf{K}$ & $\mathbf{M g}$ & $\mathbf{T i}$ & $\mathbf{N a}$ & $\mathbf{F e}$ & $\mathbf{M n}$ & $\mathbf{S}$ & Other & LOI \\
\hline Geopolymer & 46.9 & 20.8 & 12.6 & 15.3 & 0.62 & 1.34 & 0.78 & 0.18 & 0.57 & 0.22 & 0.18 & 0.51 & 2.56 \\
Basalt ground fiber & 39.4 & 31.8 & 18.0 & 9.2 & 0.6 & 0.4 & 0.3 & 0.3 & 0.1 & - & - & - & 2.05 \\
\hline
\end{tabular}

LOI: Loss on Ignition.

\subsection{Sample Preparation}

The samples in this study were made using five parts by weight of cement and four parts by weight of activator, which was recommended by the suppliers of Baucis LK, and the mixture was stirred for five minutes at RT until the solution was homogenized. Next, the geopolymer was mixed with $30 \%$ basalt ground fiber by comparing the ratio of cement, and the mixture was homogenized for a further five minutes. Aluminum powder was then added at the end of the mixture preparation for about one minute at high speed. Directly after mixing, the fresh GFs were cast into molds. Plastic sheets then covered the samples until they became hard enough to be removed.

\subsection{Characterizations}

The samples were tested at different curing temperatures and different aging times. The purpose of this was to analyze the conditions for which the GF must be prepared in order to have best mechanical properties. The specimens were cured for 2, 4, 612 and $24 \mathrm{~h}$ at room temperature and 50,70,85 and $105^{\circ} \mathrm{C}$. For each temperature, three-point flexure, compressive test and apparent density measurements were set after 3, 7, 14 and 28 days.

The apparent density of GF was measured according to standard ČSN EN 1936. The mass, height, width and length of each sample were measured to calculate the apparent density of the sample measurement for the flexure test.

The strength tests used a universal testing machine-Instron (Model 4202, Labortech s.r.o, Opava, Czech Republic). The sample dimensions for the flexure test were $40 \mathrm{~mm}$ by $40 \mathrm{~mm}$ by $160 \mathrm{~mm}$ (Figure 1a); for each test, three samples were tested. The flexural tests were conducted with a crosshead speed of $2.0 \mathrm{~mm} / \mathrm{min}$ at RT (about $22 \pm 3{ }^{\circ} \mathrm{C}$ ) and a span length of $120 \mathrm{~mm}$. For the compression test, the broken parts from the samples used in the flexure test were used, making a total of six samples for this case (Figure 1b); their dimensions were $40 \mathrm{~mm} \times 40 \mathrm{~mm} \times 40 \mathrm{~mm}$ (Figure 1c). 

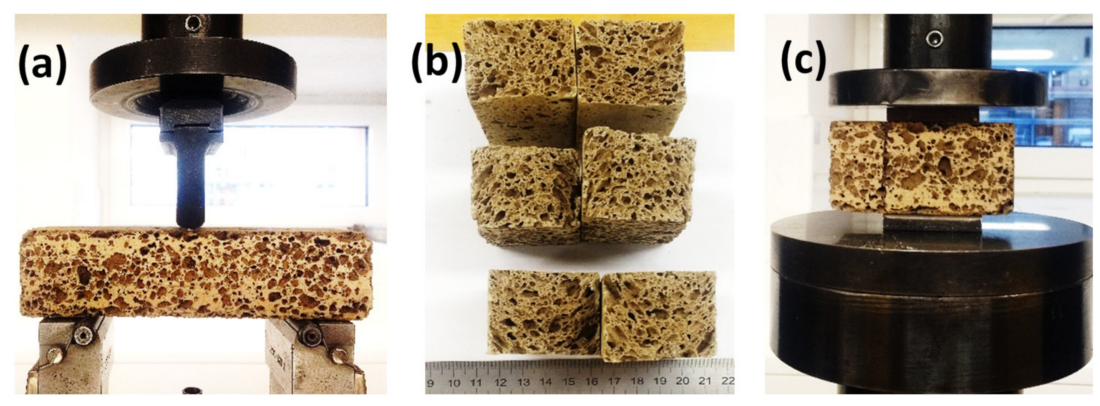

Figure 1. (a) Three-point flexure test, (b) broken samples, (c) compression test.

The fire resistance tests were conducted on aluminum plates coated with a GF layer. Fire resistance specimens were fabricated by coating the GF mixture on the aluminum plates' surface by casting, and plates were cured for 28 days at RT before testing. The thicknesses of the aluminum plates before coating with the GF layer were $2 \mathrm{~mm}$. The fire resistance samples had a 2D dimension of $300 \mathrm{~mm} \times 300 \mathrm{~mm}$. The fire exposure region of the samples was $200 \mathrm{~mm} \times 200 \mathrm{~mm}$. The thicknesses of the coated GF layers for the fire resistance specimens were measured from three samples with different thicknesses of 10, $20 \mathrm{~mm}$ and uncoated. The inside and outside temperatures of the fire test furnace were measured using in-built thermocouples connected to the computer. The thermocouples' hot sides and cold sides were mounted on the fire-exposed surface of the specimen and the unexposed sample surface, respectively. A system of natural gas heated the test furnace. The endpoint of the fire resistance test for aluminum specimens was reached when the measured temperature on the unexposed surface of samples reached $210{ }^{\circ} \mathrm{C}$ using an infrared thermometer-C. A. 1950 Diaca (CHAUVIN ARNOUX GROUP, Asnières-SurSeine, France). The furnace fire was controlled to obtain the heating rate recommended in the standard ISO 834.

\section{Results and Discussion}

Figures 2 and 3 show the effect of curing temperature and time on the flexural and compressive strength of the geopolymer at 3, 7, 14 and 28 days. GF cured at RT reached a flexural strength of $1.27 \mathrm{MPa}$ and compressive strength of $2.75 \mathrm{MPa}$ at 28 days. The flexural, compressive strength and apparent density of GF cured at ambient temperature after 28 days gave a reference result for comparing investigated values. The strength of GF with an early curing age and cured at $50{ }^{\circ} \mathrm{C}$ was not significantly lower than those of the GFs cured at 70,85 and $105^{\circ} \mathrm{C}$ due to the slow settling of the geopolymer mixture. A higher temperature increases the hard structure formation of the GF, thereby increasing its strength. The flexural and compressive strengths of the GF cured at 50, 70, 85 and $105^{\circ} \mathrm{C}$, respectively, reached their final values $2 \mathrm{~h}$ after mixing. The flexural and compressive strengths after being cured for three days at $85{ }^{\circ} \mathrm{C}$ for $2 \mathrm{~h}$ increased $111 \%$ and $122.9 \%$, respectively, compared to the samples cured at RT after 28 days. After $24 \mathrm{~h}$ at $85^{\circ} \mathrm{C}$, the flexural and compressive strengths after three days increased, respectively, $119.7 \%$ and $128.4 \%$ compared to those at RT for 28 days. Meanwhile, GF cured at $50{ }^{\circ} \mathrm{C}$ grew slowly, and its quality was better than at the start of the experiment. However, the compressive strength after 28 days was not significantly lower than that of the GF cured at RT. In contrast, although the mixtures cured at 70,85 and $105^{\circ} \mathrm{C}$ exhibited rapid strength development, they achieved their target strength values three days after mixing. In the early ages, the compressive strength increased with increasing temperature; the level of geopolymerization was higher, increasing the samples' strength. On the other hand, with longer ages, when the geopolymerization level was approximately the same, the samples' strengths were similar. The flexural strengths of test pieces cured at different temperatures and times showed a similar development trend to compressive strength. The flexural and compressive strengths of GF were described as a function of the curing time at different temperatures. The final values of compressive strength were reached after about three days, 
whereas these values were reached for samples cured at RT after 28 days. The curing times of the strength development of the GFs treated at 50, 70, 85 and $105^{\circ} \mathrm{C}$ were very similar. Samples cured for $2 \mathrm{~h}$ at high temperature reached their final strength after three days with flexural and compressive strength values of about 2.8 and $1.2 \mathrm{MPa}$, respectively. As observed in Figure $3 c$, the compressive strengths of GF after 3 days at $85^{\circ} \mathrm{C}$ after soaking of $2,4,6,12$ and $24 \mathrm{~h}$, respectively, were $3.38,3.36,3.15,3.32$ and $3.53 \mathrm{MPa}$, and they increased by $22.9 \%, 22.2 \%, 14.5 \%, 20.7 \%$ and $28.4 \%$ compared to the sample cured at RT after 28 days. Meanwhile, when the GF was cured at $85^{\circ} \mathrm{C}$, the development trend of the GF compressive strength was very similar at $3,7,14$ and 28 days. In this case, the compressive strength at three days was equal to or higher than $3.2 \mathrm{MPa}$, but furthermore, the final compressive strength was not reduced.
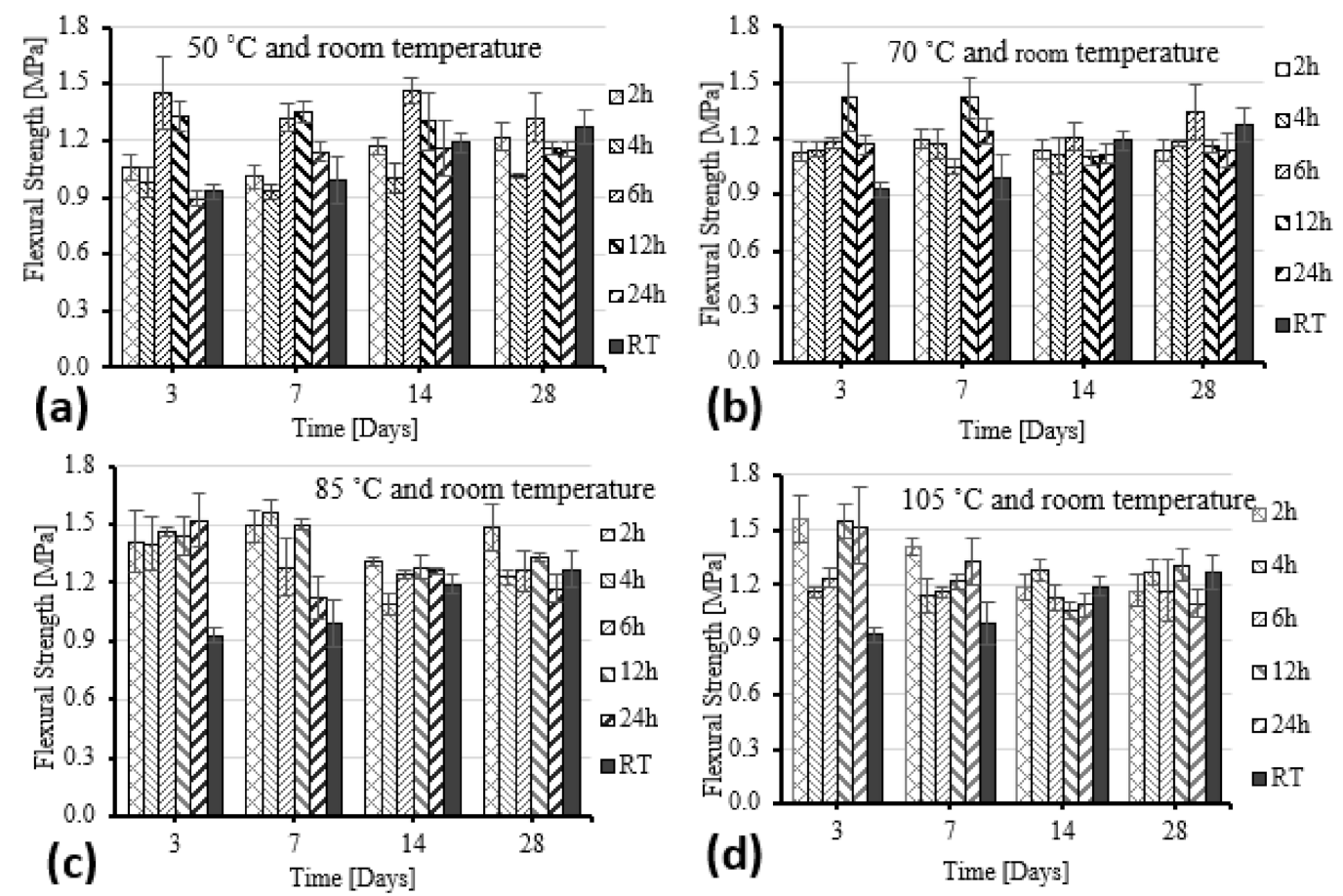

Figure 2. Flexural strengths of geopolymer foam (GF) at different curing temperatures: (a) $50{ }^{\circ} \mathrm{C},(\mathbf{b}) 70{ }^{\circ} \mathrm{C},(\mathbf{c}) 85^{\circ} \mathrm{C}$ and (d) $105^{\circ} \mathrm{C}$.

Interestingly, the compressive and flexural strength of GF samples were most significantly improved under curing conditions of $85^{\circ} \mathrm{C}$, whereas the samples cured at $105^{\circ} \mathrm{C}$ showed a decrease in their compressive and flexural strength. This reduction was due to the rapid curing and the fast water loss from the geopolymer structure [8,45]. Besides, all samples showed significant improvements in compressive and flexural strength as curing conditions increased from 50 to $105^{\circ} \mathrm{C}$ compared to the values at RT. The improvement in the mechanical strength of GFs under curing at $85^{\circ} \mathrm{C}$ could be expressed in terms of curing and porosity [10].

The apparent density of GF at different curing temperatures is depicted in Figure 4. The apparent density of GF cured at RT decreased over time and ranged from 0.706 to $0.586 \mathrm{~g} / \mathrm{cm}^{3}$. It was shown that the increase in curing time and temperature slightly significantly decreased the apparent density of GF. Furthermore, the sample becoming lighter over time may have been due to the extra loss of unreacted water during geopolymerization. In studies, it has been shown that the density of GF after 28 days at room temperature is stable $[8,19,50-52]$. In all results regarding density at the age of 3 days, there was a higher apparent density value after curing for 28 days. At seven days, the apparent density of all samples decreased compared to its apparent density at three days. Then, it became almost constant after seven days, and the apparent density of specimens cured at 50, 70, 85 and 
$105^{\circ} \mathrm{C}$ was significantly unchanged, as visible in the red line for $0.586 \mathrm{~g} / \mathrm{cm}^{3}$ in Figure 4 . The results indicated that the apparent density of GF after seven days at all temperature checks was equivalent to its apparent density cured at 28 days. Therefore, the apparent density values of the GF were stable on the seventh day. The condition and mechanical properties of the GF samples from this work and the literature are depicted in Table 2, in which the results of the investigation are presented regarding GF treated at 40,60,70 and $80^{\circ} \mathrm{C}$ for 24,96 and $168 \mathrm{~h}$ and they were measured after seven or more days. The results of the study were compared with previous studies with time correlation.
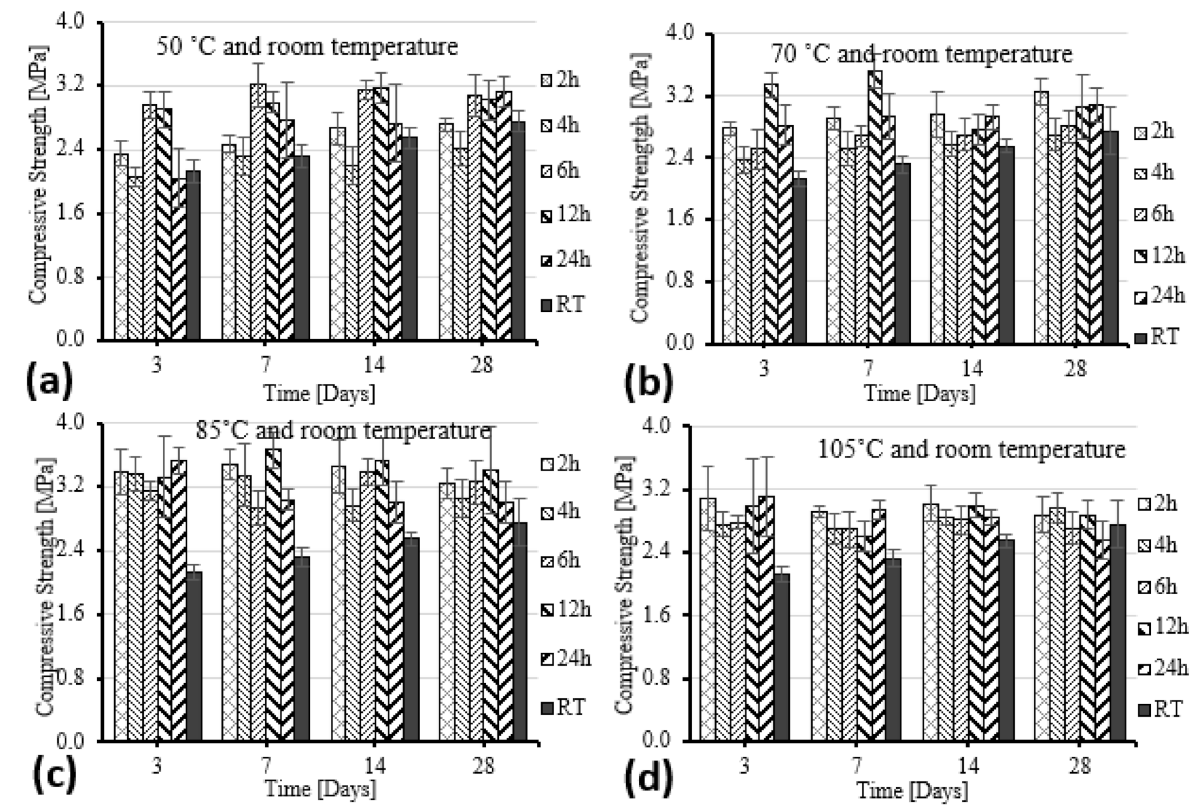

Figure 3. Compressive strength of GF at different curing temperatures: (a) $50^{\circ} \mathrm{C}$, (b) $70{ }^{\circ} \mathrm{C}$, (c) $85^{\circ} \mathrm{C}$ and (d) $105^{\circ} \mathrm{C}$.
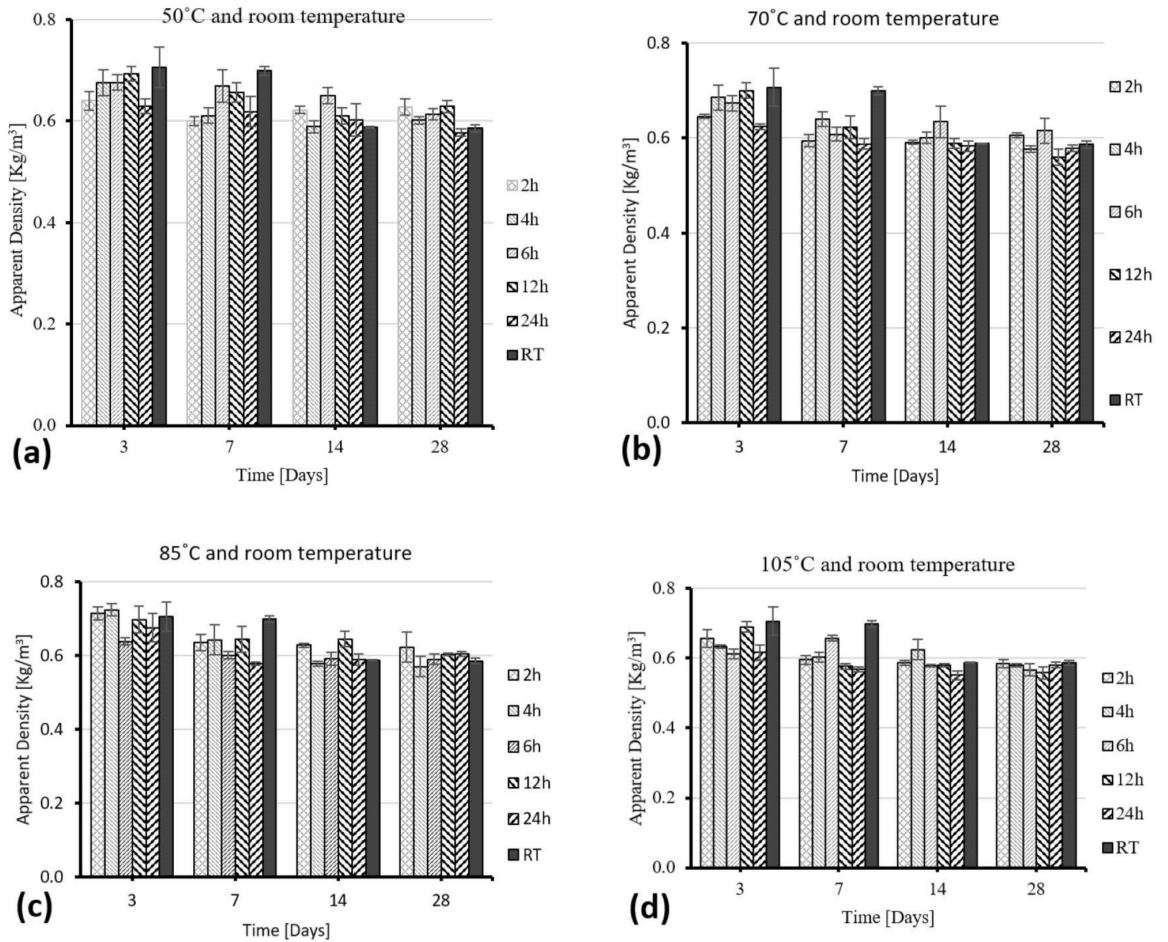

Figure 4. Apparent density of GF at different curing temperatures: (a) $50{ }^{\circ} \mathrm{C}$, (b) $70{ }^{\circ} \mathrm{C},(\mathbf{c}) 85^{\circ} \mathrm{C}$ and (d) $105^{\circ} \mathrm{C}$. 
Table 2. The condition and mechanical properties of GF from this work and literature.

\begin{tabular}{|c|c|c|c|c|c|c|}
\hline CTI (h) & CTE $\left({ }^{\circ} \mathrm{C}\right)$ & TT (Days) & CS (MPa) & FS (MPa) & $D\left(\mathrm{~g} / \mathrm{cm}^{3}\right)$ & Ref. \\
\hline 5 & 80 & 28 & $0.3-3$ & - & $0.45-0.75$ & [8] \\
\hline 10 & 80 & 28 & 0.55 & - & 0.37 & [53] \\
\hline 24 & 60 & 7 & $0.42-1.59$ & - & - & [54] \\
\hline 24 & 60 & 28 & 1.45 & - & 0.31 & [55] \\
\hline 24 & 60 & - & $0.57-5.9$ & - & $0.21-1$ & [5] \\
\hline 24 & 70 & 28 & 3.07 & - & 0.92 & \\
\hline 24 & 40 & 28 & $4.23-14.8$ & - & $0.10-0.16$ & [6] \\
\hline 24 & 70 & - & $2.9-9.3$ & $2-3.6$ & $0.64-1$ & [7] \\
\hline 24 & $40 / 75$ & 28 & $2.3-30.7$ & - & $0.37-0.87$ & [16] \\
\hline 24 & 75 & - & $2.19-3.11$ & - & $0.4-0.51$ & [9] \\
\hline 24 & 85 & - & $0.67-0.96 /$ & - & $0.239-0.335$ & [46] \\
\hline 96 & 40 & 7 & 4.5 & - & 0.54 & [37] \\
\hline 168 & 60 & - & $0.06-1.56$ & - & $0.21-0.63$ & {$[4]$} \\
\hline- & $\mathrm{RT}$ & 28 & 1.3 & - & 0.6 & [56] \\
\hline $2 / 4 / 6 / 12 / 24$ & $20 / 50 / 70 / 85 / 105$ & $3 / 7 / 14 / 28$ & $2.75-3.5$ & $0.9-1.5$ & $0.56-0.62$ & This work \\
\hline
\end{tabular}

CTI: curing time, CTE: curing temperature, TT: test time, CS: compressive strength, FS: flexural strength, D: density, RT: room temperature.

Besides, the increase in the flexural strength of GF was clearly explained by the flexural load-displacement curve analysis. The effects of curing time and temperature and aging on the flexural load-displacement curves of the GF samples are clearly shown in Figure 5, where the samples cured at RT are representative. With soak times increasing at high curing temperatures, the load-bearing capacity can be obviously seen to decrease in Figure 5a. The shape of curves changed positively with an increasing soak time at $85^{\circ} \mathrm{C}$. While samples cured at RT broke smoothly due to the native of the first crack, increasing soak times at high curing temperatures affected the test pieces, the method of breaking of which improved and became a soft fracture.
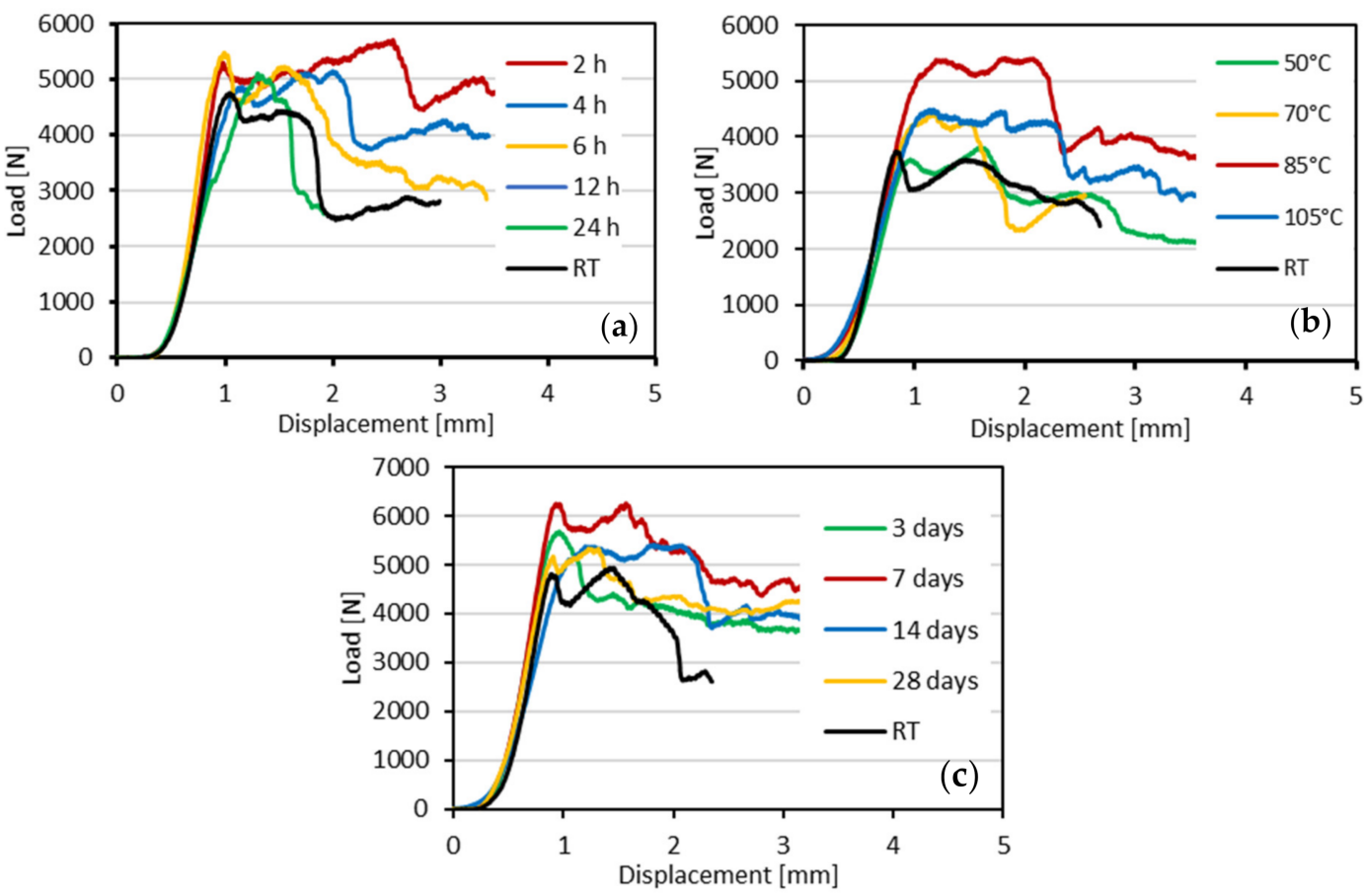

Figure 5. Flexural load-displacement behavior of GF under different conditions: (a) at $85^{\circ} \mathrm{C}$ for $2,4,6,12,24$ and RT after 28 days, (b) at 50,70, 85 and $105^{\circ} \mathrm{C}$ and RT for $2 \mathrm{~h}$ after 7 days, (c) at $85^{\circ} \mathrm{C}$ for $2 \mathrm{~h}$ after $3,7,14$ and 28 days.

Furthermore, the dropping length of the flexural load-displacement curves is also precisely related to the rate of reinforcement, and the shapes of the curves are considerably 
different. The maximum load for specimens was performed under curing at $85^{\circ} \mathrm{C}$ and soaking for $2 \mathrm{~h}$. A similar argument can be put forward for the samples maintained at RT, 50, 70, 85 and $105{ }^{\circ} \mathrm{C}$, as shown in Figure 5b. On the other hand, the loads of the samples with increasing curing time to achieve a hard displacement state were even greater than that at RT, and the maximum load of GF was under curing at $85^{\circ} \mathrm{C}$ for $2 \mathrm{~h}$. Figure $5 \mathrm{c}$ shows the flexural load-displacement curves of the samples after aging for 3, 7, 14 and 28 days and curing at $85^{\circ} \mathrm{C}$ for $2 \mathrm{~h}$. After only 3 days, the sample's load was greater than that at room temperature. At 7 days of age, the load of the sample was maximum. Surprisingly, the load of the test samples decreased after 14 and 28 days.

The failure modes of GFs specimens are described in Figure 6. The effect of compressive force deformed the sample, as shown in Figure $6 \mathrm{~b}$, with cracked shapes appearing around the center of the cube, although the sides of the cube were not completely broken. This shows that stress was maintained and that the load was transferred to another region of the matrix through the fibers (Figure 6c). Therefore, the first cracks were not localized with increasing applied load. Instead, new cracks developed elsewhere in the geopolymer matrix. As a result, an increase in the applied load resulted in multiple cracks and a higher load capacity. Besides, the strength of GFs changed with different sizes of the specimen. For instance, the compressive strength of the $50 \mathrm{~mm}$ cube increased by $15 \%$ compared with the $100 \mathrm{~mm}$ cube [11], or the compressive strength determined by cubic specimens was almost $15 \%$ higher than that obtained in cylindrical specimens $[11,57]$. In this work, the specimens tested for compressive strength were cubes with sizes of $40 \mathrm{~mm} \times 40 \mathrm{~mm} \times 40 \mathrm{~mm}$.

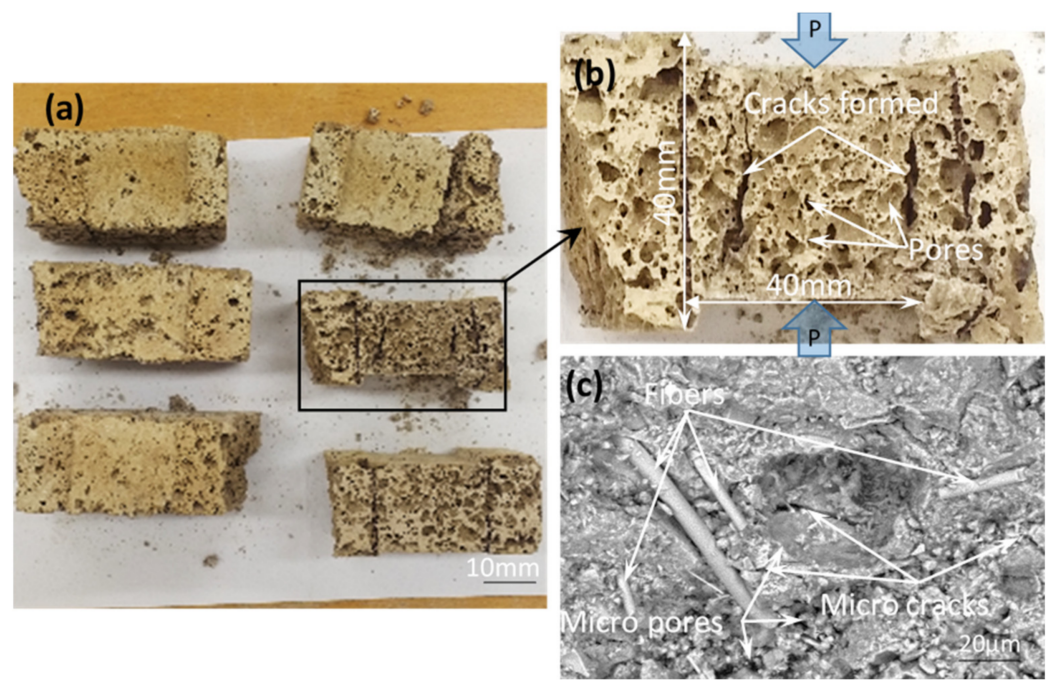

Figure 6. Failure modes of GF specimens: (a) the compression test of the broken parts, (b) surface failure of samples, and (c) micrograph of GFs.

Fire resistance testing was performed on the aluminum plates coated by GF layers of different thicknesses using the flame from a gas burner. Temperature-time curves of fire resistance tests for different coating layer thicknesses are shown in Figure 7: (a) uncoated sample, (b) sample with a $10 \mathrm{~mm}$ coating and (c) sample with a $20 \mathrm{~mm}$ coating. The fire resistance time of the uncoated sample was $250 \mathrm{~s}$. The fire resistance times of GF samples coated with 10 and $20 \mathrm{~mm}$ layers were 4000 and $7500 \mathrm{~s}$, respectively. The aluminum plate covered with a protective GF layer of $20 \mathrm{~mm}$ in thickness resisted the fire for the longest time. Its fire-resistance time was 30 times longer than that of the aluminum plate without the GF layer. The maximal temperature in the furnace did not exceed $600{ }^{\circ} \mathrm{C}$. The aluminum plate covered with a protective GF layer of $10 \mathrm{~mm}$ in thickness showed a fire-resistance time that was 16 times longer than that of the uncoated sample, while the fire temperature in the furnace increased to $600^{\circ} \mathrm{C}$. The top-end condition was determined as a cold-side temperature greater than $210^{\circ} \mathrm{C}$, as measured by an infrared thermometer (C. A. 1950 Diaca (Figure 7d)). 

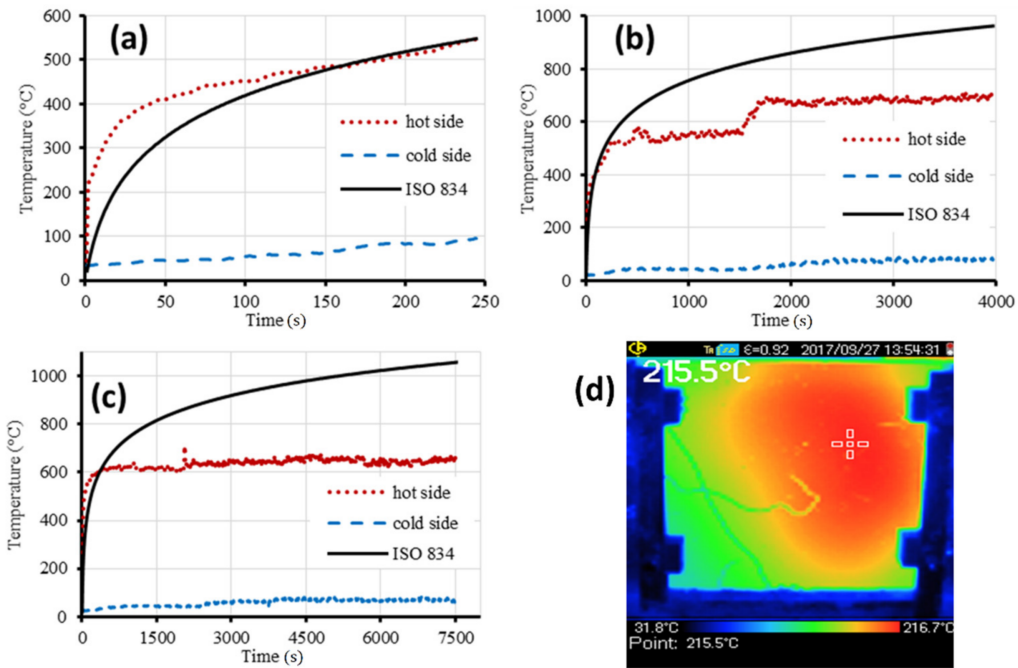

(d)

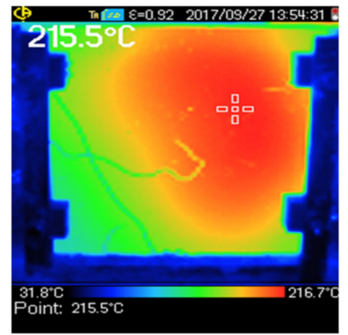

Figure 7. Temperature-time curves of fire resistance tests for different coating layer thicknesses: (a) uncoated, (b) $10 \mathrm{~mm}$, (c) $20 \mathrm{~mm}$ and (d) the cold-side temperature.

Micrographs and photographs of the surface of the GF are shown in Figure 8. Figure $8 \mathrm{a}, \mathrm{b}$ shows the micropore, fiber and GF matrix in the GF structure at room temperature and after firing. Figure $8 \mathrm{~b}$ shows that the fibers still exist in the GF structure and there is no change in comparison with the GF structure before and after firing. Figure $8 \mathrm{c}$ shows the almost totally distributed porosity of the surface sample. Porosity occupies most of the GF structure, with amorphous pores, which is the cause of the increase in heat transfer in the geopolymer structure [9,22]. The exposed surface of the sample did not show any change in deformation or fracture. The change was visible by the light color. The sample exposed to fire (Figure 8e) had a lighter gray color than the unexposed sample (Figure 8d). The GF exposed to high temperatures had a hardened surface. Temperatures at around $600{ }^{\circ} \mathrm{C}$ did not affect the GF structure but made it more stiffened. In addition, it is known that the geopolymer can withstand temperatures as high as $1000{ }^{\circ} \mathrm{C}[14,19,58-61]$. The results of the experiment showed that the aluminum plate coated with a protective GF layer significantly increased its fire resistance time. Therefore, the aluminum plate coated with the GF layer could be used for good insulation and fire prevention at temperatures around $600{ }^{\circ} \mathrm{C}$. Moreover, the geopolymer composite was coated on base substrates such as wood, concrete and steel for passive fire protection $[12-14,18,19]$. It is clear from this study that the GF is suitable for coating on aluminum plates for fire protection. 


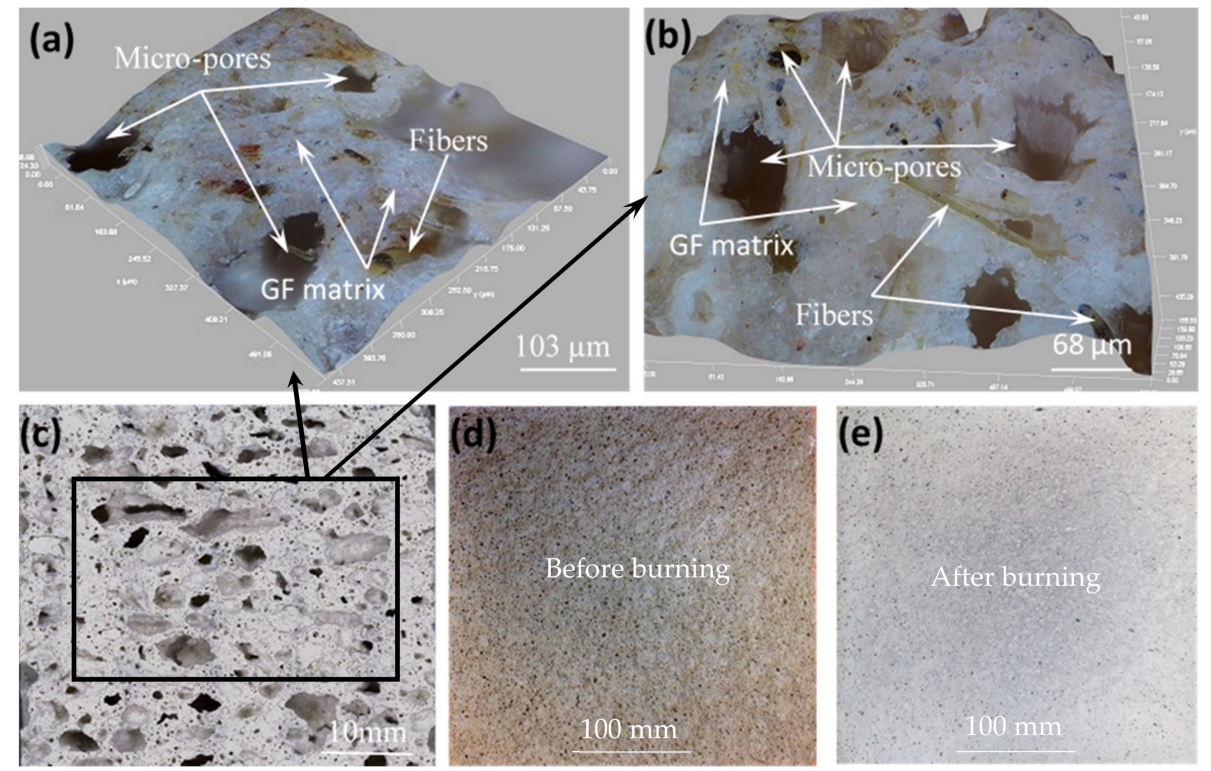

Figure 8. Micrographs and photographs of the GF surface: (a,d) before test, $(\mathbf{b}, \mathbf{e})$ after test and (c) cross-section of $40 \mathrm{~mm}$ by $40 \mathrm{~mm}$.

\section{Conclusions}

In this research, the effects of curing temperature and time at different temperatures on the mechanical properties of GF with basalt fiber reinforcement and a foaming agent with aluminum powder were investigated by measuring the development of its flexural and compressive strength over time. In addition, this study presented the fire resistance of the studied GF-coated aluminum plate. The experimental and analytical results allow us to make the following conclusions.

- All samples showed significant improvements in compressive and flexural strength as curing conditions increased from 50 to $105{ }^{\circ} \mathrm{C}$ compared to at RT. The compressive and flexural strength of GF was most significantly improved under the curing condition of $85^{\circ} \mathrm{C}$.

- The maximum load for specimens was found after curing for 7 days at $85^{\circ} \mathrm{C}$ and soaking for $2 \mathrm{~h}$; surprisingly, the load of the test samples decreased after 14 and 28 days.

- The apparent density of the GF was stable at the age of 7 days.

- The aluminum plate covered with a protective GF layer showed an increased fire resistance time compared to the unprotected plate. The aluminum plate covered with a protective GF layer of $20 \mathrm{~mm}$ in thickness resisted the fire for the longest time. Its fire-resistance time was 30 times higher than that of the aluminum plate without the GF layer. The maximal temperature in the furnace did not exceed $600{ }^{\circ} \mathrm{C}$.

- Temperatures at around $600{ }^{\circ} \mathrm{C}$ did not affect the GF structure but made it more stiffened.

The results indicated that GF has the potential for fast production while retaining its mechanical properties, thereby reducing the demands of the production process, and it is a light-weight material for fire prevention and resistance as a building material. Further studies are necessary in future research papers because the sample's parameters may change after 3, 12, 36 and 60 months.

Author Contributions: Conceptualization, methodology, software, validation, formal analysis, investigation, resources, data curation, V.S.L.; writing—original draft preparation, V.S.L.; writing—review and editing, V.S.L. and P.L.; supervision, P.L.; project administration, P.L. All authors have read and agreed to the published version of the manuscript.

Funding: This research received no external funding.

Institutional Review Board Statement: Not applicable. 
Informed Consent Statement: Not applicable.

Data Availability Statement: The data presented in this study are available in article.

Acknowledgments: The publication is grateful to the Ministry of Education, Youth and Sports of the Czech Republic for the financial support of the Institutional Endowment for Long-Term Conceptual Development and the Department of Material Science, Faculty of Mechanical Engineering, Technical University of Liberec.

Conflicts of Interest: The authors declare no conflict of interest.

\section{References}

1. Davidovits, J. Geopolymer Chemistry and Application Saint-Quentin: Institut Geopolymere; Institut Géopolymère: Saint-Quentin, France, 2015.

2. Davidovits, J. Properties of geopolymer cements. In Proceedings of the First International Conference on Alkaline Cements and Concretes, Kiev, Ukraine, 11-14 October 1994; pp. 131-149.

3. Davidovits, J. Geopolymers: Man-made rock geosynthesis and the resulting development of very early high strength cement. J. Mater. Educ. 1994, 16, 91.

4. Yan, S.; Zhang, F.; Liu, J.; Ren, B.; He, P.; Jia, D.; Yang, J. Green synthesis of high porosity waste gangue microsphere/geopolymer composite foams via hydrogen peroxide modification. J. Clean. Prod. 2019, 227, 483-494. [CrossRef]

5. Petlitckaia, S.; Poulesquen, A. Design of lightweight metakaolin based geopolymer foamed with hydrogen peroxide. Ceram. Int. 2019, 45, 1322-1330. [CrossRef]

6. Leiva, C.; Luna-Galiano, Y.; Arenas, C.; Alonso-Fariñas, B.; Fernández-Pereira, C. A porous geopolymer based on aluminum-waste with acoustic properties. Waste Manag. 2019, 95, 504-512. [CrossRef] [PubMed]

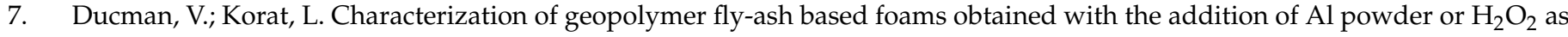
foaming agents. Mater. Charact. 2016, 113, 207-213. [CrossRef]

8. Cilla, M.S.; Colombo, P.; Morelli, M.R. Geopolymer foams by gelcasting. Ceram. Int. 2014, 40, 5723-5730. [CrossRef]

9. Bai, C.; Franchin, G.; Elsayed, H.; Conte, A.; Colombo, P. High strength metakaolin-based geopolymer foams with variable macroporous structure. J. Eur. Ceram. Soc. 2016, 36, 4243-4249. [CrossRef]

10. Rovnaník, P. Effect of curing temperature on the development of hard structure of metakaolin-based geopolymer. Constr. Build. Mater. 2010, 24, 1176-1183. [CrossRef]

11. Hamad, A.J. Size and shape effect of specimen on the compressive strength of HPLWFC reinforced with glass fibres. J. King Saud Univ. Eng. Sci. 2017, 29, 373-380. [CrossRef]

12. Davidovits, J. Process for the Fabrication of Sintered Panels and Panels Resulting from the Application of This Process. U.S. Patent No. 3,950,470, 13 April 1976.

13. Sakkas, K.; Panias, D.; Nomikos, P.; Sofianos, A. Potassium based geopolymer for passive fire protection of concrete tunnels linings. Tunn. Undergr. Space Technol. 2014, 43, 148-156. [CrossRef]

14. Temuujin, J.; Minjigmaa, A.; Rickard, W.; Lee, M.; Williams, I.; van Riessen, A. Preparation of metakaolin based geopolymer coatings on metal substrates as thermal barriers. Appl. Clay Sci. 2009, 46, 265-270. [CrossRef]

15. Davidovits, J. Years of successes and failures in geopolymer applications. Market trends and potential breakthroughs. In Proceedings of the Geopolymer 2002 Conference, Melbourne, Australia, 28-29 October 2002; p. 29.

16. Bai, C.; Franchin, G.; Elsayed, H.; Zaggia, A.; Conte, L.; Li, H.; Colombo, P. High-porosity geopolymer foams with tailored porosity for thermal insulation and wastewater treatment. J. Mater. Res. 2017, 32, 3251-3259. [CrossRef]

17. Zhang, Y.J.; Liu, L.C.; Xu, Y.; Wang, Y.C. A new alkali-activated steel slag-based cementitious material for photocatalytic degradation of organic pollutant from waste water. J. Hazard. Mater. 2012, 209, 146-150. [CrossRef] [PubMed]

18. Sakkas, K.; Sofianos, A.; Nomikos, P.; Panias, D. Behaviour of passive fire protection K-geopolymer under successive severe fire incidents. Materials 2015, 8, 6096-6104. [CrossRef]

19. Zhang, Z.; Provis, J.L.; Reid, A.; Wang, H. Geopolymer foam concrete: An emerging material for sustainable construction. Constr. Build. Mater. 2014, 56, 113-127. [CrossRef]

20. Lecomte, I.; Liégeois, M.; Rulmont, A.; Cloots, R.; Maseri, F. Synthesis and characterization of new inorganic polymeric composites based on kaolin or white clay and on ground-granulated blast furnace slag. J. Mater. Res. 2003, 18, 2571-2579. [CrossRef]

21. Palmero, P.; Formia, A.; Antonaci, P.; Brini, S.; Tulliani, J.-M. Geopolymer technology for application-oriented dense and lightened materials. Elaboration and characterization. Ceram. Int. 2015, 41, 12967-12979. [CrossRef]

22. Novais, R.M.; Buruberri, L.; Ascensão, G.; Seabra, M.; Labrincha, J. Porous biomass fly ash-based geopolymers with tailored thermal conductivity. J. Clean. Prod. 2016, 119, 99-107. [CrossRef]

23. Hlaváček, P.; Šmilauer, V.; Škvára, F.; Kopecký, L.; Šulc, R. Inorganic foams made from alkali-activated fly ash: Mechanical, chemical and physical properties. J. Eur. Ceram. Soc. 2015, 35, 703-709. [CrossRef]

24. Kamseu, E.; Nait-Ali, B.; Bignozzi, M.; Leonelli, C.; Rossignol, S.; Smith, D.S. Bulk composition and microstructure dependence of effective thermal conductivity of porous inorganic polymer cements. J. Eur. Ceram. Soc. 2012, 32, 1593-1603. [CrossRef] 
25. Kong, D.L.; Sanjayan, J.G. Damage behavior of geopolymer composites exposed to elevated temperatures. Cem. Concr. Compos. 2008, 30, 986-991. [CrossRef]

26. Chiu, Y.-P.; Lu, Y.-M.; Shiau, Y.-C. Applying inorganic geopolymers added with aluminium powder to fire-resistant fillers. Mater. Res. Innov. 2015, 19, S5-642-S5-649. [CrossRef]

27. Abdullah, M.M.A.; Hussin, K.; Bnhussain, M.; Ismail, K.N.; Yahya, Z.; Razak, R.A. Fly Ash-based geopolymer lightweight concrete using foaming agent. Int. J. Mol. Sci. 2012, 13, 7186-7198. [CrossRef] [PubMed]

28. Shi, C. Composition of Materials for Use in Cellular Lightweight Concrete and Methods Thereof. U.S. Patents No. 6,488,762, 3 December 2002.

29. Zhang, Z.; Provis, J.L.; Reid, A.; Wang, H. Mechanical, thermal insulation, thermal resistance and acoustic absorption properties of geopolymer foam concrete. Cem. Concr. Compos. 2015, 62, 97-105. [CrossRef]

30. Building, C.M.A. Thermal insulation products for buildings. In Factory Made Mineral Wool (MW) Products, Specification ed.; ROCKWOOL: Bohumin, Czech Republic, 2015; p. 52.

31. Abdollahnejad, Z.; Pacheco-Torgal, F.; Félix, T.; Tahri, W.; Aguiar, J.B. Mix design, properties and cost analysis of fly ash-based geopolymer foam. Constr. Build. Mater. 2015, 80, 18-30. [CrossRef]

32. Mo, B.-H.; Zhu, H.; Cui, X.-m.; He, Y.; Gong, S.-Y. Effect of curing temperature on geopolymerization of metakaolin-based geopolymers. Appl. Clay Sci. 2014, 99, 144-148. [CrossRef]

33. Asdrubali, F.; D'Alessandro, F.; Schiavoni, S. A review of unconventional sustainable building insulation materials. Sustain. Mater. Technol. 2015, 4, 1-17. [CrossRef]

34. Kamseu, E.; Ceron, B.; Tobias, H.; Leonelli, E.; Bignozzi, M.C.; Muscio, A.; Libbra, A. Insulating behavior of metakaolin-based geopolymer materials assess with heat flux meter and laser flash techniques. J. Therm. Anal. Calorim. 2011, 108, 1189-1199. [CrossRef]

35. Zhou, X.-Y.; Zheng, F.; Li, H.-G.; Lu, C.-L. An environment-friendly thermal insulation material from cotton stalk fibers. Energy Build. 2010, 42, 1070-1074. [CrossRef]

36. Mallicoat, S.; Sarin, P.; Kriven, W. Novel, alkali-bonded, ceramic filtration membranes. In Proceedings of the Developments in Advanced Ceramics and Composites: A Collection of Papers Presented at the 29th International Conference on Advanced Ceramics and Composites, Cocoa Beach, FL, USA, 23-28 January 2005, Ceramic Engineering and Science Proceedings; John Wiley \& Sons: Hoboken, NJ, USA, 2009; Volume 298, p. 37.

37. Bai, C.; Colombo, P. High-porosity geopolymer membrane supports by peroxide route with the addition of egg white as surfactant. Ceram. Int. 2017, 43, 2267-2273. [CrossRef]

38. Ge, Y.; Yuan, Y.; Wang, K.; He, Y.; Cui, X. Preparation of geopolymer-based inorganic membrane for removing $\mathrm{Ni}^{2+}$ from wastewater. J. Hazard. Mater. 2015, 299, 711-718. [CrossRef] [PubMed]

39. Ahmaruzzaman, M. Industrial wastes as low-cost potential adsorbents for the treatment of wastewater laden with heavy metals. Adv. Colloid Interface Sci. 2011, 166, 36-59. [CrossRef] [PubMed]

40. López, F.J.; Sugita, S.; Tagaya, M.; Kobayashi, T. Metakaolin-based geopolymers for targeted adsorbents to heavy metal ion separation. J. Mater. Sci. Chem. Eng. 2014, 2, 16. [CrossRef]

41. Minelli, M.; Medri, V.; Papa, E.; Miccio, F.; Landi, E.; Doghieri, F. Geopolymers as solid adsorbent for $\mathrm{CO}_{2}$ capture. Chem. Eng. Sci. 2016, 148, 267-274. [CrossRef]

42. Luukkonen, T.; Sarkkinen, M.; Kemppainen, K.; Rämö, J.; Lassi, U. Metakaolin geopolymer characterization and application for ammonium removal from model solutions and landfill leachate. Appl. Clay Sci. 2016, 119, 266-276. [CrossRef]

43. Sharma, S.; Medpelli, D.; Chen, S.; Seo, D.-K. Calcium-modified hierarchically porous aluminosilicate geopolymer as a highly efficient regenerable catalyst for biodiesel production. Rsc Adv. 2015, 5, 65454-65461. [CrossRef]

44. Gong, W.; Lutze, W.; Pegg, I.L. High-Strength Geopolymer Composite Cellular Concrete. U.S. Patents No. 9,919,974, 20 March 2018.

45. Feng, J.; Zhang, R.; Gong, L.; Li, Y.; Cao, W.; Cheng, X. Development of porous fly ash-based geopolymer with low thermal conductivity. Mater. Des. 2015, 65, 529-533. [CrossRef]

46. Henon, J.; Alzina, A.; Absi, J.; Smith, D.S.; Rossignol, S. Potassium geopolymer foams made with silica fume pore forming agent for thermal insulation. J. Porous Mater. 2012, 20, 37-46. [CrossRef]

47. Skvara, F.; Sulc, R.; Zdenek, T.; Petr, S.; Vit, S.; Zuzana, Z.C. Preparation and properties of fly ash-based geopolymer foams. Ceram. -Silik. 2014, 58, 188-197.

48. Kearsley, E.P.; Wainwright, J.P. The effect of porosity on the strength of foamed concrete. Cem. Concr. Res. 2020, 23, 233-239. [CrossRef]

49. Le, V.S.; Szczypinski, M.M.; Hájková, P.; Kovacic, V.; Bakalova, T.; Volesky, L.; Louda, P. Mechanical properties of geopolymer foam at high temperature. Sci. Eng. Compos. Mater. 2020, 27, 129. [CrossRef]

50. Ye, J.; Zhang, W.; Shi, D. Effect of elevated temperature on the properties of geopolymer synthesized from calcined ore-dressing tailing of bauxite and ground-granulated blast furnace slag. Constr. Build. Mater. 2014, 69, 41-48. [CrossRef]

51. Zhang, Z.; Wang, H.; Yao, X.; Zhu, Y. Effects of halloysite in kaolin on the formation and properties of geopolymers. Cem. Concr. Compos. 2012, 34, 709-715. [CrossRef]

52. Davidovits, J. Geopolymer Chemistry and Applications, 2nd ed.; Institute Geopolymere: Saint Quentin, France, 2008. 
53. Liu, Y.; Yan, C.; Zhang, Z.; Gong, Y.; Wang, H.; Qiu, X. A facile method for preparation of floatable and permeable fly ash-based geopolymer block. Mater. Lett. 2016, 185, 370-373. [CrossRef]

54. Hajimohammadi, A.; Ngo, T.; Mendis, P.; Sanjayan, J. Regulating the chemical foaming reaction to control the porosity of geopolymer foams. Mater. Des. 2017, 120, 255-265. [CrossRef]

55. Cui, Y.; Wang, D.; Zhao, J.; Li, D.; Ng, S.; Rui, Y. Effect of calcium stearate based foam stabilizer on pore characteristics and thermal conductivity of geopolymer foam material. J. Build. Eng. 2018, 20, 21-29. [CrossRef]

56. Hassan, H.S.; Abdel-Gawwad, H.; García, S.V.; Israde-Alcántara, I. Fabrication and characterization of thermally-insulating coconut ash-based geopolymer foam. Waste Manag. 2018, 80, 235-240. [CrossRef]

57. Mehta, P.K.; Monteiro, P.J. Concrete: Microstructure, Properties, and Materials; McGraw-Hill Education: New York, NY, USA, 2014.

58. Zhao, Y.; Jow, J.; Cai, X.; Lai, S.Y. Fly ash-based geopolymer foam technology for thermal insulation and fire protection applications. In Proceedings of the 2015 World of Coal Ash (WOCA), Nashville, TN, USA, 5-7 May 2015; pp. 5-7.

59. Ranjbar, N.; Mehrali, M.; Alengaram, U.J.; Metselaar, H.S.C.; Jumaat, M.Z. Compressive strength and microstructural analysis of fly ash/palm oil fuel ash based geopolymer mortar under elevated temperatures. Constr. Build. Mater. 2014, 65, 114-121. [CrossRef]

60. Aredes, F.; Campos, T.; Machado, J.; Sakane, K.; Thim, G.; Brunelli, D. Effect of cure temperature on the formation of metakaolinitebased geopolymer. Ceram. Int. 2015, 41, 7302-7311. [CrossRef]

61. Chithambaram, S.J.; Kumar, S.; Prasad, M. Thermo-mechanical characteristics of geopolymer mortar. Constr. Build. Mater. 2019, 213, 100-108. [CrossRef] 